\title{
THE CRAMBE (Crambe abyssinica Hochst) BYPRODUCTS, CAN BE USED AS A SOURCE OF NON-DEGRADABLE PROTEIN IN THE RUMEN?
}

\section{COPRODUTOS DE CRAMBE (Crambe abyssinica Hochst) PODEM SER UTILIZADOS COMO FONTE DE PROTEINA NÃO DEGRÁDAVEL NO RÚMEN?}

\author{
Rafael Henrique de Tonissi e Buschinelli de GOES ${ }^{1}$; Rosiélen Augusto PATUSSI ${ }^{2}$; \\ Jefferson Rodrigues GANDRA ${ }^{1}$; Antonio Ferriani BRANCO ${ }^{3}$; \\ Thiago José de Lira CARDOSO² ${ }^{2}$ Marcus Vinícius Moraes de OLIVEIRA ${ }^{4}$; \\ Raquel Tenório de OLIVEIRA ${ }^{5}$; Charles Jhonnatan dos Santos SOUZA ${ }^{5}$ \\ 1. Professor, Doutor, Faculdade de Ciências Agrárias. Universidade Federal da Grande Dourados - UFGD, Dourados, MS, Brasil. \\ rafaelgoes@ufgd.edu.br; 2. Mestre em Zootecnia, Programa de Pós-Graduação em Zootecnia, UFGD, Dourados, MS. Brasil; 3. \\ Professor, Doutor, Departamento de Zootecnia - DZO, Universidade Estadual de Maringá, Maringá, PR, Brasil; 4. Professor, Doutor, \\ Universidade Estadual de Mato Grosso do Sul - UEMS, Aquidauana, MS, Brasil; 5. Estudante de Graduação em Zootecnia, UFGD, \\ Dourados, MS, Brasil.
}

\begin{abstract}
To evaluated the chemical composition and ruminal degradability of crambe byproducts (meal and crushed) and proteic supplements formulated with crushed crambe $(0 ; 2.5 ; 5 ; 10$ and 15\%); five crossbred steers with average weight of $485 \pm 14 \mathrm{~kg}$, were used. All the animal were kept in individual paddocks of 0.25 ha on Urochloa brizantha (syn. Brachiaria brizantha). It was observed a greater soluble fraction, higher effective degradability at $5 \% / \mathrm{h}$ and higher degradation rate "c" and, consequent, lower indigestible fraction for crambe crushed ground in the sieve of 3 $\mathrm{mm}$. The effective degradability at $5 \% / \mathrm{h}$ was lower for the crambe crushed (55.42) in relation to the meal (48.80). The diet with $5 \%$ of inclusion of crambe showed higher effective degradability for dry matter $(54.86 \%)$ and lower fraction "I" $(30.64 \%)$ associated with higher fractions "c" and "b". Crambe ground in sieves of 1 and $3 \mathrm{~mm}$ mesh presented the highest degradability. Crushed crambe showed higher ruminal degradation than crambe meal; the crambe byproducts possibility can be use as a source of non-degradable protein in the rumen.
\end{abstract}

KEYWORDS: Crambe meal. Crushed crambe. In situ degradability.

\section{INTRODUCTION}

Oilseeds are used in ruminant diets due to their high concentrations of lipids, and composition of fatty acids, rich in unsaturated fatty acids $(\omega-3$ and $\omega-6)$, and because they present a slow release of oil, due to chewing, which results in small fractions coming into the rumen (CIEŚLAK et al., 2013).

Crambe (Crambe abyssinica Hochst) has been widely used for the extraction of oil for biodiesel production. Vegetable oils used for biodiesel production can be extracted from oilseeds through two different processes: with the use of solvents or by pressing. The waste from the use of solvents for oil extraction is meal and from pressing, crushed grain. The seed has between 46 and 58\% CP with 44\% EE (Souza et al. 2009; Goes et al., 2010). Crambe meal contains about $47.4 \mu \mathrm{mol} / \mathrm{g}$ of glucosinolates [(S)-2-hydroxy-3-butenyl glucosinolate]; and it's toxic $(11-24,3 \mathrm{~mol} / \mathrm{g})$ to many organisms and impairs the activity of rumen flora in cattle after six days of ingestion (TRIPATHI; MISHRA, 2007).

Considering the high nutritional potential of this oilseed, and if crambe products can be used in ruminant nutrition, the present study evaluated by the in situ technic the kinetic patterns of ruminal degradation of dry matter and crude protein of crambe byproducts, and, degradability of supplements with inclusion of crushed crambe replacing soybean meal.

\section{MATERIAL AND METHODS}

The experiments were conducted at the Sector of Ruminant Nutrition and Animal Nutrition Laboratory of the Federal University of Grande Dourados. In both experiments we used, crossbred steers with average weight of $485 \pm 14 \mathrm{~kg}$, cannulated in the rumen were kept in individual paddocks $(0.25$ ha) of Urochloa brizantha (syn. Brachiaria brizantha) cv. Marandu (7047.85 kg of DM/ha); receiving daily, in the morning $(8: 00 \mathrm{~h}), 8 \mathrm{~g} / \mathrm{kg}$ body weight of supplement containing crushed crambe (Table 1).

\section{Experiment 1}

Crambe byproducts (crushed and meal) were evaluated in two trials; on the first trial we evaluated the ruminal degradability of crambe 
crushed at different particle size (1,3 and $5 \mathrm{~mm})$ and the second trial were evaluated the ruminal degradability of crambe meal and crambe crushed grounded at $3 \mathrm{~mm}$. The chemical composition of crambe byproducts presents in Table 2 . In both trials the crushed crambe was obtained by cold pressing.

Table 1. Percentual to the experimental supplements.

\begin{tabular}{lccccc}
\hline Ingredients $(\mathrm{g} / \mathrm{kg})$ & $\mathrm{C} 0$ & $\mathrm{C} 2.5$ & $\mathrm{C} 5$ & $\mathrm{C} 10$ & $\mathrm{C} 15$ \\
\hline Crushed crambe & - & 25 & 50 & 100 & 150 \\
Soybean meal & 150 & 125 & 100 & 50 & - \\
Rice meal & 400 & 400 & 400 & 400 & 400 \\
Corn meal & 376 & 375 & 373 & 369 & 366 \\
Urea & 3.5 & 5.2 & 7.0 & 10.5 & 14 \\
Salt & 10 & 10 & 10 & 10 & 10 \\
Limestone & 25 & 25 & 25 & 25 & 25 \\
Sulfur & 10 & 10 & 10 & 10 & 10 \\
Dicalcium phosphate & 15 & 15 & 15 & 15 & 15 \\
Premix $^{2}$ & 10 & 10 & 10 & 10 & 10 \\
\hline
\end{tabular}

${ }^{\mathrm{T}} \mathrm{C} 00=$ supplement without crambe crushed; $\mathrm{C} 2.5=$ supplement with $2.5 \%$ crambe crushed; $\mathrm{C} 5=$ supplement with $5 \%$ crambe crushed; $\mathrm{C} 10=$ supplement with $10 \%$ crambe crushed; $\mathrm{C} 15=$ supplement with $15 \%$ crambe crushed. ${ }^{2} \mathrm{Calcium}: 120.00 \mathrm{~g}$. phosphorus: $88.00 \mathrm{~g}$. iodine: $75.00 \mathrm{mg}$. manganese: $1300.00 \mathrm{mg}$. sodium: $126.00 \mathrm{~g}$. selenium: $15.00 \mathrm{mg}$. sulfur: $12.00 \mathrm{mg}$. zinc: $3630.00 \mathrm{mg}$. cobalt: 55.50 mg. cooper: $1530.00 \mathrm{mg}$ e iron: $1800.00 \mathrm{mg}$.

Table 2. Chemical composition $(\mathrm{g} / \mathrm{kg}$ ) and in vitro dry matter digestibility (IVDMD) (\%) of crambe byproducts.

\begin{tabular}{lcccccccc}
\hline Feedstuffs & DM & OM & CP & EE & NDF & ADF & LIG & IVDMD \\
\hline Crushed Crambe & 943.0 & 952.2 & 261.9 & 182.7 & 302.3 & 194.4 & 84.0 & 62,04 \\
Crambe Meal & 899.0 & 931.9 & 350.0 & 41.0 & 350.0 & 242.0 & 113.0 & 58,61 \\
\hline
\end{tabular}

$\mathrm{DM}=$ Dry matter, $\mathrm{OM}=$ organic matter, $\mathrm{CP}=$ crude protein, $\mathrm{EE}=$ ether extract, $\mathrm{NDF}=$ neutral detergent fiber, $\mathrm{ADF}=$ acid detergent fiber, $\mathrm{MM}=$ mineral matter, $\mathrm{LIG}=$ lignin.

The feedstuffs were analyzed to dry matter (DM - method 930.15); ash (Ash - method 942.05) and the organic matter $(\mathrm{OM}=100-$ ash $)$; crude protein (CP - method 976.05, N X 6.25) and ether extract (EE - method 920.39), following the methodologies of AOAC (2006). ADF contents were obtained following method described by Van Soest and Robertson (1985). Lignin content was obtained by oxidation with potassium permanganate (VAN SOEST; WINE, 1968). For analysis of NDF, samples were treated with heat stable alpha amylase without sodium sulfite and corrected for ash residue (MERTENS, 2002).

The feedstuffs were dried at $65^{\circ} \mathrm{C}$ for 24 hours, removed, and weighed. After weighing, the food was packed in TNT bags (TNT $-100 \mathrm{~g} / \mathrm{m}^{2}$ ) in size $5.0 \times 5.0 \mathrm{~cm}$, respecting the relationship $20 \mathrm{mg}$ $/ \mathrm{cm}^{2}$ (CASALI et al. 2009). The samples were prepared and incubated according to Nocek (1988) and Huntington \& Givens (1995). TNT Bags were introduced directly into the rumen, in decreasing order of 48, 36, 24, 12, 8, 4, 2 and 0 hours, in triplicates per animal/incubation time, according to NRC (2001); and . removed all at once and rinsed in tap water, until clean. The remaining residues from the incubation were oven dried at $65^{\circ} \mathrm{C}$ for $48 \mathrm{~h}$ and stored for later analysis to determine the variables studied.

The disappearance of dry matter and crude protein $(\mathrm{N} \times 6.25)$ were based on the weight difference between the incubated material and the residues after incubation. To estimate the kinetic parameters of DM and $\mathrm{CP}$, we used the first-order asymptotic model described of Ørskov e McDonald (1979): $P D=a+b\left(1-e^{-c t}\right)$. Where: $P D=$ potential rumen degradability; $\mathrm{a}=$ soluble fraction; $b=$ potentially degradable fraction of the insoluble fraction that would be degraded at a rate c; $c=$ degradation rate of the fraction " $b$ "; $t=$ incubation time in hours.

The fraction considered as undegradable is calculated according to Ørskov \& McDonald (1979): $I=100-(a+b)$. And the effective degradability (ED) is calculated with the following equation: $\quad \mathrm{ED}=\mathrm{a}+\left[\left(\mathrm{b}^{*} \mathrm{c}\right) /(\mathrm{c}+\mathrm{K})\right]$; where $\mathrm{K}=$ passage rate of solids from the rumen, herein defined as 2, 5 and $8.0 \%$ per hour (h), which can be attributed to the low, medium and high dietary intake. After fitting the data to the model and using the disappearance value obtained at the time zero (a'), we estimated the colonization time (CT) as proposed by Patiño et al. (2001), where the 
parameters $\mathrm{a}, \mathrm{b}$ and $\mathrm{c}$ were estimated by the Gauss Newton algorithm: $\mathrm{TC}=\left[-\ln \left(\mathrm{a}^{\prime}-\mathrm{a}-\mathrm{b}\right) / \mathrm{c}\right]$.

\section{Experiment 2}

The inclusion levels of crambe crushed in the concentrates was $0 ; 2.5 ; 5.0 ; 10$ and $15 \%$ (Table 1). Three samples were taken of each concentrate, which were placed in plastic bags, identified and stored at $-20^{\circ} \mathrm{C}$.

For in situ degradability, the protein supplements were ground in $3 \mathrm{~mm}$ sieve, and then dried at $65^{\circ} \mathrm{C}$ for 24 hours and weighed. Bags were introduced directly into the rumen, in descending order of $48,36,24,12,8,4,2$ and 0 hours, in triplicate per animal/incubation time, according to NRC (2001). Each supplement was incubated in an animal receiving the same treatment. The rest of the methodologies used in the in situ degradability trial of protein supplements were similar to those in the experiment 1 .

\section{Statistical analysis}

The animals were distributed in a randomized latin square design (5x5); and the degradation curves of dry matter and crude protein of feedstuffs evaluated, for each animal used, were subjected to fit by the respective models using the PROC NLIN of SAS 9.2. The in vitro dry matter digestibility was analyzed by polynomial regression PROG REG of SAS 9.2, with significance level of $5 \%$.

\section{RESULTS}

\section{Experiment 1 - trial 1}

The kinetic parameters of in situ degradation for different particle sizes of crushed crambe were similar, with intermediate degradability for DM and CP (Table 3).

Table 3. Kinetic parameters of in situ degradation of crushed crambe in different particle sizes

\begin{tabular}{|c|c|c|c|c|c|c|c|c|c|}
\hline \multirow[b]{2}{*}{ Dry matter } & \multicolumn{3}{|c|}{ Parameters* } & \multirow[b]{2}{*}{$\mathrm{I}(\%)$} & \multicolumn{4}{|c|}{ Effective degradability $\left(\% \cdot \mathrm{h}^{-1}\right)$} & \multirow[b]{2}{*}{$\begin{array}{c}\mathrm{CT} \\
(\mathrm{min})\end{array}$} \\
\hline & $\mathrm{a}(\%)$ & $\mathrm{b}(\%)$ & $\mathrm{c}(\% / \mathrm{h})$ & & 2 & 5 & 8 & $r^{2}$ & \\
\hline $1 \mathrm{~mm}$ & 27.86 & 22.24 & 0.08 & 49.90 & 45.31 & 41.16 & 38.65 & 88.75 & 342 \\
\hline $3 \mathrm{~mm}$ & 28.16 & 27.01 & 0.17 & 44.82 & 47.83 & 43.21 & 40.80 & 97.04 & 346 \\
\hline $5 \mathrm{~mm}$ & 26.20 & 23.37 & 0.07 & 50.42 & 44.11 & 39.46 & 36.73 & 91.49 & 353 \\
\hline \multicolumn{10}{|c|}{ Crude protein } \\
\hline $1 \mathrm{~mm}$ & 25.64 & 36.89 & 0.25 & 37.47 & 59.71 & 56.24 & 53.43 & 90.90 & 301 \\
\hline $3 \mathrm{~mm}$ & 31.55 & 28.56 & 0.31 & 39.89 & 58.36 & 56.11 & 54.21 & 88.28 & 271 \\
\hline $5 \mathrm{~mm}$ & 34.33 & 28.67 & 0.19 & 37.00 & 59.15 & 55.42 & 52.88 & 74.27 & 314 \\
\hline
\end{tabular}

$* a=$ soluble fraction; $b=$ potentially degradable fraction; $c=$ degradation rate of fraction $\mathrm{b}$. I=indigestible fraction. CT = Time of colonization (minutes)

It was observed a greater soluble fraction, higher effective degradability at $5 \% \cdot \mathrm{h}^{-1}$ and degradation rate "c", consequent, lower indigestible fraction for feedstuffs grounded of $3 \mathrm{~mm}(28.16 \%$, $43.21 \%$ and $44.82 \%$, respectively).

The crushed crambe grounded of $3 \mathrm{~mm}$ showed the highest degradation rates, and greater potentially degradable fraction of DM. For CP, the ground in the $5 \mathrm{~mm}$ demonstrated the highest soluble fraction, which did not result in higher effective degradability. The soluble fraction observed for the ground of $5 \mathrm{~mm}$ was $34.33 \%$, but this value not correspond a greater effective degradability at $5 \% \cdot \mathrm{h}^{-1}(55.42 \%)$, lower than that found for the sieves of 1 and $3 \mathrm{~mm}$.

\section{Experiment 1 - trial 2}

The kinetic parameters of in situ degradability, there was a higher percentage for the fraction "a" and fraction "I" for the DM of the crushed crambe (Table 4). In turn, the meal showed higher percentage of the fractions " $b$ " and "c" $(\% \cdot h$ " $\left.{ }^{1}\right)$. Also, we observed a low degradability at $5 \% \cdot \mathrm{h}^{-1}$ for both byproducts.

The crushed presents a higher value for fraction "a" and "c", by CP, and the meal have a higher percentage of the fractions " $b$ ". The effective degradability at $5 \% \cdot \mathrm{h}^{-1}$ was lower for the crushed crambe $(55.42 \%)$ in relation to the meal $(48.80 \%)$.

\section{Experiment 2}

The crushes crambe reduces the NDF of supplements, but increases the EE (Table 5).

The diet with $5 \%$ of inclusion showed higher effective degradability for dry matter $(54.86 \%)$ and lower fraction "I" (30.64\%) associated with higher fractions "c" and "b". The lower soluble fraction "a" and lower effective degradability at $5 \% \cdot \mathrm{h}^{-1}$, were verified in the $10 \%$ of 
inclusion, with 6.68 and $49.08 \%$ respectively for

DM (Table 6).

Table 4. Kinetic parameters of in situ degradation crambe byproducts.

\begin{tabular}{|c|c|c|c|c|c|c|c|c|c|}
\hline \multirow[b]{2}{*}{ Dry matter } & \multicolumn{3}{|c|}{ Parameters* } & \multirow[b]{2}{*}{$\mathrm{I}(\%)$} & \multicolumn{4}{|c|}{$\begin{array}{l}\text { Effective degrabability } \\
\left(\% \cdot \mathrm{h}^{-1}\right)\end{array}$} & \multirow{2}{*}{$\begin{array}{l}\mathrm{CT} \\
(\min )\end{array}$} \\
\hline & $\mathrm{a}(\%)$ & $\mathrm{b}(\%)$ & $\mathrm{c}(\% / \mathrm{h})$ & & 2 & 5 & 8 & $\mathrm{r}^{2}$ & \\
\hline Crushed & 26.20 & 23.17 & 0.07 & 50.63 & 43.96 & 39.35 & 36.64 & 91.49 & 353 \\
\hline Meal & 18.94 & 31.39 & 0.11 & 49.67 & 29.17 & 38.26 & 34.95 & 99.14 & 352 \\
\hline \multicolumn{10}{|l|}{$\begin{array}{l}\text { Crude } \\
\text { protein }\end{array}$} \\
\hline Crushed & 34.33 & 28.67 & 0.19 & 37.00 & 59.15 & 55.42 & 52.88 & 74.27 & 316 \\
\hline Meal & 20.68 & 43.24 & 0.10 & 36.08 & 37.44 & 48.80 & 44.05 & 94.44 & 364 \\
\hline
\end{tabular}

$* a=$ soluble fraction; $\mathrm{b}=$ potentially degradable fraction; $\mathrm{c}=$ degradation rate of fraction $\mathrm{b}$. I=indigestible fraction. $\mathrm{CT}=$ colonization time in minutes

Table 5. Chemical composition of supplements contents crushed crambe

\begin{tabular}{|c|c|c|c|c|c|c|c|c|}
\hline \multirow{2}{*}{ Nutrients ${ }^{1}$} & \multicolumn{5}{|c|}{ Levels of crushed crambe $(\%)$} & \multirow{2}{*}{ Average } & \multirow{2}{*}{$\mathrm{MSE}^{2}$} & \multirow{2}{*}{$\mathrm{P}<\mathrm{F}^{3}$} \\
\hline & 0.0 & 2.5 & 5.0 & 10.0 & 15.0 & & & \\
\hline $\mathrm{DM}$ & 926.9 & 918.5 & 936.7 & 923.6 & 922.0 & 925.5 & 0.30 & ns \\
\hline $\mathrm{OM}$ & 863.0 & 867.2 & 873.9 & 876.7 & 874.4 & 871.0 & 0.33 & ns \\
\hline $\mathrm{CP}$ & 153.4 & 148.6 & 155.0 & 155.7 & 150.0 & 152.5 & 0.35 & 0.244 \\
\hline $\mathrm{EE}$ & 96.0 & 96.3 & 99.1 & 99.8 & 114.3 & 101.1 & 0.38 & 0.145 \\
\hline NDF & 518.7 & 369.4 & 421.0 & 363.9 & 390.8 & 412.5 & 1.28 & 0.003 \\
\hline LIG & 47.2 & 25.7 & 49.1 & 28.1 & 31.3 & 35.9 & 0.21 & 0.072 \\
\hline $\mathrm{TCHO}$ & 636.5 & 647.1 & 618.0 & 631.2 & 620.0 & 630.9 & 0.69 & ns \\
\hline
\end{tabular}

${ }^{\mathrm{l}} \mathrm{DM}$ : Dry Matter (g/kg); OM = organig matter (g/kg); CP: crude protein (g/kg); EE: ether extract (g/kg); NDF: neutral detergent fiber $(\mathrm{g} / \mathrm{kg})$; LIG: lignin (g/kg); TCHO: total carbohidrates (g/kg); ${ }^{2} \mathrm{MSE}$ : mean standard error. ${ }^{3} \mathrm{~ns}$ : not significance; NDF: $\mathrm{Y}=486.3-25.0$ $\mathrm{x}\left(\mathrm{r}^{2}=0.33\right)$.

Table 6. Kinetic parameters of in situ degradation of experimental supplements

\begin{tabular}{|c|c|c|c|c|c|c|c|c|c|}
\hline \multirow{2}{*}{$\begin{array}{l}\begin{array}{l}\text { Crambe } \\
\text { Inclusion }\end{array} \\
\text { Dry matter }\end{array}$} & \multicolumn{3}{|c|}{ Parameters* } & \multirow[b]{2}{*}{$\mathrm{I}(\%)$} & \multicolumn{4}{|c|}{ Effective Degradability $\left(\% \cdot \mathrm{h}^{-1}\right)$} & \multirow[b]{2}{*}{$\begin{array}{c}\mathrm{CT} \\
(\mathrm{min})\end{array}$} \\
\hline & $\mathrm{a}(\%)$ & $\mathrm{b}(\%)$ & $\mathrm{c}(\% / \mathrm{h})$ & & 2 & 5 & 8 & $r^{2}$ & \\
\hline 00 & 13.49 & 54.19 & 0.1161 & 32.32 & 59.71 & 51.36 & 45.57 & 97.40 & 369 \\
\hline 2.5 & 8.49 & 58.61 & 0.1283 & 32.90 & 59.19 & 50.66 & 44.59 & 97.67 & 367 \\
\hline 5.0 & 10.54 & 58.82 & 0.1528 & 30.64 & 62.55 & 54.86 & 49.15 & 97.90 & 357 \\
\hline 10.0 & 6.68 & 56.60 & 0.1492 & 36.72 & 56.59 & 49.08 & 43.53 & 98.00 & 356 \\
\hline 15.0 & 11.44 & 52.26 & 0.1707 & 36.30 & 58.22 & 51.86 & 47.03 & 98.30 & 343 \\
\hline \multicolumn{10}{|c|}{ Crude protein } \\
\hline 00 & 20.32 & 48.43 & 0.0808 & 31.24 & 68.61 & 59.15 & 50.24 & 52.78 & 384 \\
\hline 2.5 & 18.67 & 44.30 & 0.1661 & 37.03 & 62.97 & 58.20 & 52.71 & 73.79 & 335 \\
\hline 5.0 & 31.20 & 44.49 & 0.0398 & 24.31 & 73.15 & 60.80 & 50.90 & 81.99 & 421 \\
\hline 10.0 & 23.63 & 42.98 & 0.1398 & 33.40 & 66.60 & 61.22 & 55.28 & 90.39 & 344 \\
\hline 15.0 & 29.52 & 39.83 & 0.2762 & 30.65 & 69.35 & 66.66 & 63.25 & 95.26 & 298 \\
\hline
\end{tabular}

$* a=$ soluble fraction; $b=$ potentially degradable fraction; $\mathrm{c}=$ degradation rate of fraction $\mathrm{b}$. I=indigestible fraction; $\mathrm{CT}=$ colonization time in minutes 
For crude protein, we observed greater soluble fraction "a" for the diet C5 (31.20\%) and lower fraction "I" (24.31\%), which did not promote the greater effective degradability at $5 \% \cdot \mathrm{h}^{-1}$, which was observed for $15 \%$ of inclusion $(66.66 \%)$.

\section{DISCUSSION}

\section{Experiment 1 - trial 1}

The results of in situ degradability kinetics indicated little variation in parameters between the three sieves (1, 3 and $5 \mathrm{~mm}$ ) (Table 3 ). Ruminant digestive processes are influenced by the particle size of the feed and its flow through the rumen. Despite having ground the feedstuffs evaluated to increase the contact area, all feedstuffs showed an intermediate degradation with similar colonization times.

Physical and chemical characteristics interfere with feed degradability, where lower contents of NDF are related to greater capacity for water retention (QUEIROZ et al. 2010). The water holding capacity strongly affects the colonization by microorganisms (DU et al., 2010) and can influence the filling effect, altering the passage rate.

Moreover, several alternatives have been evaluated to decrease protein degradability in the rumen and thereby enable better availability of amino acids for intestinal digestion (SANTOS et al., 2004). According to Carlson et al. (1996) and Anderson et al. (2000), crambe is a good source of cysteine, methionine, lysine, alanine, glutamate, aspartate and threonine, thus manipulating the amino acid profile in the duodenum may be interesting, but this can reduce the contribution of nitrogen for microbial synthesis. The kinetics of crude protein degradation corresponds to the kinetics of dry matter. The soluble fraction for the byproduct grounded at $5 \mathrm{~mm}$ was $34.33 \%$, however this value does not correspond to a higher effective degradability at $5 \% \cdot \mathrm{h}^{-1}$. This indicates that the particle size does not influence the crude protein degradability, and the soluble fraction of this nutrient was high for all particle sizes used.

\section{Experiment 1- trial 2}

Considering the chemical composition of the crushed crambe, Souza et al. (2009) observed $317.9 \mathrm{~g} / \mathrm{kg}$ of CP and Goes et al. (2010) found CP value of $528.0 \mathrm{~g} / \mathrm{kg}$, higher than that observed in this study.

To the kinetic parameters of in situ degradation for dry matter, both byproducts showed a low effective degradability at $5 \% \cdot \mathrm{h}^{-1}$. Goes et al. (2010) examined the crushed crambe reported
$60.43 \%$ of effective degradability at $5 \% \cdot \mathrm{h}^{-1}$. The low degradability may be associated with low values presented by the potentially degradable fraction (b), similar to that found by Brás et al. (2014), which resulted in high values for the undegradable fraction, and low degradation rate. Nevertheless, crushed crambe showed higher soluble fraction for dry matter, as also observed by Goes et al., (2010).

The difference in kinetics of degradation between byproducts can be related to the pressing process. According to Beran et al. (2005), pressing of seeds cause compaction, which after milling may result in smaller particles and facilitate the solubilization. Brás et al. (2014) pointed out that the degradability presented, may be associated with rumen not be propitious to microbial action, due to anti-nutritional factors, such as erucic acid.

The difference between the values for fraction "a" may be related to the hydration capacity of the source. Higher solubility values are associated with reduction of potentially degradable fraction. In addition to the water-holding capacity, physical parameter is critical to the determination of degradability, including the fiber content (QUEIROZ et al., 2010). Foods with less density retaining feature between the cell wall matrix which can retain the free water in the rumen (SEOANE et al., 1981).

Carlson et al. (1996) evidenced that hull and grain have low degradation (44.5 and 57.3\%), and that the degradability of dehulled crambe meal is similar to soybean meal. Liu et al. (1994) analyzed the partially hulled crambe and found low ruminal degradation, which was associated with high content of EE. In the present study, even with higher values of EE, the crushed showed a behavior similar to that of the meal, indicating that oil content did not interfere CP degradability.

In relation to the colonization time, we observed close values for dry matter (353and 352 minutes). However, for crude protein, the colonization time for crambe crushed was shorter than for the meal (316 and 364 minutes), which may explain the higher values of degradation rate and, consequently, higher values of degradability. The water holding capacity has a substantial impact on the colonization by microorganisms thus explaining the values obtained for the crambe crushed.

The short colonization time for crude protein along with higher soluble fraction and effective degradability of crushed crambe shows that this feedstuff can be used for animal feeding as a source of protein for rumen microorganisms, as it is readily degraded in the rumen at a short time. 


\section{Experiment 2}

When studied the ruminal kinetics of crushed crambe, Brás et al. (2014) and Goes et al. (2010) reported a mean effective degradability of DM ranging from 54.00 to $60.43 \%$, similar to the value verified in the present study, but the soluble fraction of concentrates with crambe crushed was lower. Differences in soluble fraction of DM may arise from the oil extraction process, in which some heating occurs during pressing, making the fraction less available, which can be related to the degradation rate "c". The intermediate degradability presented by the crambe crushed can be because the rumen environment and microbial activity, leading to reduced intake, weight loss, due to antinutritional factors, but the dry matter colonization time was shorter for the highest concentration of crambe. Primo (2013) analyzed microbial activity in the rumen fluid of steers supplemented with the same levels of this study found a reduction in $25 \%$ when $15 \%$ of crushed crambe was added in diet.

According to Liu et al. (1994), crushed crambe presents high ruminal degradability, small proportion of slowly degradable protein and degradation rate of $11.4 \% / \mathrm{h}$. The highest solubility presented by supplements may be associated with the presence of urea (Table 1).

Carlson et al. (1996) and Anderson et al. (2000), showed that amino acid profile of crambe maybe participate in the hepatic gluconeogenesis in ruminants, indicating that the manipulation of the amino acid profile in the duodenum can be interesting because protein sources of low degradability enable such manipulation, but this can reduce the contribution of nitrogen for microbial synthesis.
GOES, R. H. T. B. et al.

Higher degradation may lead to oil availability in the rumen, however, the supplementation of lipids in the diet for ruminants can bring problems associated with the reduced degradation of the fibrous fraction of the diet and changes in rumen metabolism. The crambe is rich in polyunsaturated fatty acids, which may be biohydrogenated by rumen protozoa and bacteria providing increased energy availability (GOES et al. 2010).

\section{CONCLUSIONS}

Crambe byproducts possibility can be use as a source of non-degradable protein in the rumen.

Crambe crushed showed higher ruminal degradation than crambe meal; and the feeds grounded at $3 \mathrm{~mm}$ mesh presented the highest degradability values for $\mathrm{CP}$.

\section{ACKNOWLEDGEMENTS}

We thanks to Conselho Nacional de Desenvolvimento Científico e Tecnológico (CNPq) and Fundação ao Apoio ao Desenvolvimento do Ensino Ciência e Tecnologia do Mato Grosso do Sul (Fundect) for financially supporting this work, the Universidade Federal da Grande Dourados (UFGD), CAPES and CNPq by scholarships granted. The MS Foundation, in the person of the researcher Renato Roscoe, for donating the crambe byproducts. In addition, the authors express appreciation to the Maria Gizelma de Menezes Gressler for for their assinstence with chemical analyses.

RESUMO: Para se avaliar a composição química, degradabilidade ruminal, o tempo da colonização da torta e do farelo de crambe e de suplementos protéico compostos de torta de crambe $(0 ; 2,5 ; 5,0 ; 10$ e $15 \%)$; foram utilizados cinco novilhos mestiços, com peso médio de $485 \pm 14 \mathrm{~kg}$. Todos os animais foram mantidos em piquetes individuais de 0,25 ha em pastagens de Urochloa brizantha (syn. Brachiaria brizantha). Observou-se uma fração solúvel maior, maior degradabilidade efetiva para a taxa de passagem de 5\% / h e maior taxa de degradação "c" e, consequentemente, menor fração indigerível para a torta de crambe moído na peneira de $3 \mathrm{~mm}$. A degradabilidade efetiva a 5\% / h foi menor para a torta de crambe $(55,42)$ em relação ao farelo $(48,80)$. A dieta com adição de $5 \%$ de torta de crambe apresentou maior degradabilidade efetiva da matéria seca $(54,86 \%)$ e menor fração "I" $(30,64 \%)$, associada com as frações mais elevadas "c" e "b". A torta de Crambe moída em peneiras de 1 e $3 \mathrm{~mm}$ de diâmetro apresentaram os maiores valores de degradabilidade. A torta de apresenta maior degradação ruminal que o farelo de crambe. Os coprodutos de crambe possivelmente podem ser usados como fonte de proteína não degradada no rúmen.

PALAVRAS-CHAVE: Cinética de degradação. Degradabilidade in situ. Farelo de crambe. Torta de crambe. 


\section{REFERENCES}

AHMAD T., ASLAM, Z., RASSOL S. Reducing fiber content of sunflower oil meal through treatment of enzimes produced from Arachnoitus sp. Journal Animal Science, Champaign, v. 75, n. 03, p. 231-235, 2004. https://doi.org/10.1111/j.1740-0929.2004.00181.x

ANDERSON, V. L.; CATON, J. S; KIRSCH, J. D; REDMER, D. A. Effect of crambe meal on performance, reproduction, and thyroid hormone levels in gestating and lactating beef cows. Journal of Animal Science, Champaign, v. 78, n. 9, p. 2269-2274. 2000. https://doi.org/10.2527/2000.7892269x

AOAC. Official Methods of Analysis. 15th ed. Association of Official Analytical Chemists. Arlington, 1298p. 2006.

BERAN, F. H. B., SILVA L. D. F., RIBEIRO E. L. A., CASTRO V. S., CORREIA, R. A., KAGUEYAMA, E. O., ROCHA, M. A. Degradabilidade ruminal in situ da matéria seca, matéria orgânica e proteína bruta de alguns suplementos concentrados usados na alimentação de bovinos. Semina: Ciências Agrárias, Londrina, v. 26, n. 3, p. 405-418. 2005. https://doi.org/10.5433/1679-0359.2005v26n3p405

BRÁS, P.; POSSENTI, R. A.; BUENO, M. S.; CANOVA, E. B.; SCHAMMAS. E. A. Avaliação nutricional de coprodutos da extração de óleos vegetais em dieta de ovinos. Boletim de Indústria Animal, Nova Odessa, v. 71, n. 2, p. 160-175, 2014.

CARLSON, K. D.; GARDNER, J. C.; ANDERSON, V. L., HANZEL, J. J. Crambe: new crop success. In: JANICK, J. (Ed.). Prog. in new crops. Alexandria: ASHS Press, 1996, p. 306-322.

CASALI, A. O., DETMANN, E., VALADARES FILHO, S. C.; PEREIRA, J.C.; CUNHA, M.; DETMANN, K.S.C.; PAULINO. Estimation of fibrous compounds contents in ruminant feeds with bags made from different textiles. Revista Brasileira de Zootecnia, Viçosa, v. 38, n. 01, p, 130-138, 2009.

CIEŚLAK, A.,VÁRADYOVÁ,V.,KIŠIDAYOVÁ, S., JALČ, D., SZUMACHER-STRABEL, M. Effect of diets with fruit oils supplements on rumen fermentation parameters, fatty acid composition and methane production in vitro. Journal Animal of Feed Science, Jabłonna, v. 22, n. 01, p. 26-34. 2013. https://doi.org/10.22358/jafs/66013/2013

DU, J. P., XIN, H. S., WAN, R., SHI, F. S., MENG, Q. X. Fermentation kinetics of carbohydrate fractions of maize grains as determined by in vitro gas production curve subtraction technique. Journal of Animal and Feed Science, Jabłonna, v. 19, n. 04, p. 458-467, 2010. https://doi.org/10.22358/jafs/66337/2010

GOES, R. H. T. B.; SOUZA, K. A.; PATUSSI R. A.; CORNÉLIO, T. C.; OLIVEIRA, E. R.; BRABES, K. C. S. Degradabilidade in situ dos grãos de crambe, girassol e soja, e de seus coprodutos em ovinos. Acta Scientiarum. Animal Science, Maringá, v. 32, n. 03, p. 271-277, 2010.

HUNTINGTON, J. A.; GIVENS, D. I. The in situ technique for studying the rumen degradation of feeds: A review of the procedure. Nutrition Abstracts and Review (Serie B), Oxford. v. 65, n. 2, p. 63-93, 1995.

LIU, Y. G. STEG, A., HINDLE, V. A. Rumen degradation and intestinal digestion of crambe and other oilseed byproducts in dairy cows. Animal Feed Science and Technology, Amsterdam, v. 45, n. 03-04, p. 397-409, 1994.

MERTENS, D. R. Gravimetric determination of amylase treated neutral detergent fiber in feeds with refluxing in beakers or crucibles. Collaborative study. Journal of AOAC INTERNATIONAL. Rockville. 85: 1212-1240. 2002.

NATIONAL RESEARCH COUNCIL - NRC. Nutrient requirements of dairy cattle. 7th ed. Washington, D.C.: National Academy Press, 2001. 381p. 
NOCEK, J. E. In situ and others methods to estimate ruminal protein and energy digestibility. Journal of Dairy Science, Champaign, v. 71, n. 08, p. 2051-2069, 1988. https://doi.org/10.3168/jds.S00220302(88)79781-7

$\varnothing \mathrm{RSKOV}$, E. R., McDONALD, I. The estimation of protein degradability in the rumen from incubation measurements weighted according to rate of passage. Journal of Agricultural Science, Cambridge, v. 92, n. 01, p. 499-508, 1979. https://doi.org/10.1017/S0021859600063048

PATIÑO H. O., LANGWINSKI D., SILVEIRA A. L. F. Avaliação de métodos de ajuste da curva de degradação ruminal da FDN de forragens. In: REUNIÃO ANUAL DA SOCIEDADE BRASILEIRA DE ZOOTECNIA, 38, 2001, Piracicaba. Anais... Piracicaba: Sociedade Brasileira de Zootecnia, 2001, p. 970.

PEREIRA, E. S.; MIZUBUTI, I. Y.; RIBEIRO, E. L. A.; VILLAROEL, A. B. S.; PIMENTEL, P. G. Consumo, digestibilidade aparente dos nutrientes e comportamento ingestivo de bovinos da raça Holandesa alimentados com dietas contendo feno de capim-tifton 85 com diversos tamanhos de partícula. Revista Brasileira de Zootecnia, Viçosa, v. 38, n. 1, p. 190-195. 2009.

PRIMO, R. B. S. Avaliação in vitro da microbiota ruminal utilizando torta de Crambe: Determinação da ação antimicrobiana e caracterização química das sementes de Crambe abyssinica. 2013. 70p. Dissertação (Mestrado em Ciência e Tecnologia Ambiental) - Curso de Pós-Graduação em Ciência e Tecnologia Ambiental - Universidade Federal da Grande Dourados, Dourados, 2013.

QUEIROZ, M. A. A.; SUSIN, I.; PIRES, A. V.; FERREIRA, E. M.; MENDES, C. Q.; MOURÃO, G. B. Características físico-químicas de fontes proteicas e suas interações sobrea degradação ruminal e a taxa de passagem. Revista Brasileira de Zootecnia, Viçosa, v. 39, n. 7, p. 1587-1594. 2010.

SANTOS, G. T., DAMASCENO, J. C., JOBIM, C. C., GONÇALVES, G. D., NETO, M. C., PORTO, P. P., RIBEIRO, C. R. Efeito dos tratamentos com autoclave e/ou ácido tânico na degradabilidade in situ e na degradabilidade in vitro de grãos de canola. Acta Scientiarum Animal Science, Maringá, v. 26, n. 04, p. 507512. 2004. https://doi.org/10.4025/actascianimsci.v26i4.1735

SEOANE, J. R.; COTE, M.; GERVAIS, P. Prediction on the nutritive value of alfalfa (Saranc), bromegrass (Saratoba) and timothy (Champ, Climax, Bounty) fed as hay to growing sheep. Canadian Journal of Animal Science, Ottawa, v. 61, n. 02, p. 403-413, 1981. https://doi.org/10.4141/cjas81-048

SOUZA, A. D. V.; FÁVARO, S. P.; ÍTAVO, L.,C.,V.; ROSCOE, R. Caracterização química de sementes e tortas de pinhão $\square$ manso, nabo $\square$ forrageiro e crambe. Pesquisa Agropecuária Brasileira, Brasilia, v. 44, n. 10, p. 1328-1335, 2009. https://doi.org/10.1590/S0100-204X2009001000017

TRIPATHI, M. K.; MISHRA, A. S. Glucosinolates in animal nutrition: A review. Animal and Feed Science Technology, Amsterdam, v. 132, n. 1-2, p. 1-27, 2007. https://doi.org/10.1016/j.anifeedsci.2006.03.003

VAN SOEST, P. J.; ROBERTSON, J. B. Analysis of forages and fibrous foods. : A Laboratory Manual, Ithaca: Cornell University. NY. 1985. 613p.

VAN SOEST, P. J.; WINE, R. H. Determination of Lignin and Cellulose in Acid-Detergent Fiber with Permanganate. Journal of the A.O.A.C. Rockville v. 51, n. 04, p. 780-785. 1968. 